\title{
Analisis Metode Penentuan Arah Kiblat Masjid Agung Baitul Makmur Meulaboh Aceh Barat
}

\author{
Riza Afrian Mustaqim ${ }^{1}$ \\ Dosen Ilmu Falak UIN Ar-Raniry Banda Aceh \\ ${ }^{1}$ Email: riza.mustaqim@ar-raniry.ac.id
}

\begin{abstract}
Problems related to the accuracy of the Qibla direction at the Great Mosque of Baitul Makmur Meulaboh, West Aceh cannot be tolerated. The reason is, the level of slope that occurs is so large that it does not lead to ainul ka'bah or even jihatul $k a^{\prime} b a h$. This study examines the method of determining the Qibla direction of the Great Mosque of Baitul Makmur Meulaboh, West Aceh. This type of research is a qualitative field research, by verifying the method used in determining the direction of the Qibla. The results of this study indicate that the measurement of the Qibla direction of the great mosque of Baitul Makmur Meulaboh Aceh Barat does not refer to a particular measurement method, so that it has a very significant inaccuracy.
\end{abstract}

Artikel Info

Keywords : Determination Method, Qibla Direction, Mosque

Received:

17 September 2020

Revised:

20 Oktober 2020

Accepted:

09 November 2020

Published:

02 Desember 2020

\begin{abstract}
Abstrak
Masalah ketepatan arah kiblat di Masjid Agung Baitul Makmur Meulaboh, Aceh Barat tidak bisa ditolerir. Pasalnya, tingkat kemiringan yang terjadi begitu besar sehingga tidak mengarah ke ainul ka'bah bahkan jihatul ka'bah. Penelitian ini mengkaji metode penentuan arah kiblat Masjid Agung Baitul Makmur Meulaboh Aceh Barat. Jenis penelitian ini adalah penelitian lapangan kualitatif, dengan memverifikasi metode yang digunakan dalam menentukan arah kiblat. Hasil penelitian ini menunjukkan bahwa pengukuran arah kiblat masjid Agung Baitul Makmur Meulaboh Aceh Barat tidak mengacu pada metode pengukuran tertentu, sehingga memiliki ketidaktelitian yang sangat signifikan.
\end{abstract}

Kata Kunci : Metode Penentuan, Arah Kiblat, Masjid 


\section{AL-MARSHAD: JURNAL ASTRONOMI ISLAM DAN ILMU-ILMU BERKAITAN \\ ISSN 2442-5729 (print) || ISSN 2598-2559 (online) \\ http://jurnal.umsu.ac.id/index.php/almarshad \\ DOI: 10.30596/jam.v\%vi\%i.5229|| Vol. 6, No. 2 Desember 2020}

\section{A. Pendahuluan}

Arah kiblat masjid Agung Baitul Makmur Meulaboh tidak menghadap ke Kakbah, melainkan ke kota Alem Ketema, Ethiopia yang berjarak sekitar $1.400 \mathrm{~km}$ dari Kakbah. Ketidakakuratan tersebut, dibuktikan dengan kalibrasi Rashdul Kiblat Tahunan yang terjadi pada 28 Mei 2019 yang lalu dimana terdapat kemiringan dari posisi Kakbah ke arah Selatan senilai 25 derajat (Pengamatan Rashdul Kiblat Tahunan, 28 Mei 2019, Pukul 16.18 WIB di halaman Masjid Agung Meulaboh). Kemudian kalibrasi menggunakan azimuth kiblat dengan acuan kompas arah kiblat masjid Agung Meulaboh memiliki kemiringan senilai $-30^{\circ} 52^{\prime} 46,37^{\prime \prime}$ ke arah Setalan Kakbah. Setelah diverifikasi dengan google earth (Program globe virtual yang sebenarnya) ketidakakuratan tersebut benar adanya.

Perkembangan yang mutakhir dalam ilmu ukur dan alat ukur kiblat yang medern, seharunya ketidaktepatan dalam menghadap kiblat tidak lagi terjadi, terlebih untuk tempat ibadah seperti Agung Baitul Makmur Meulaboh. Keberadaan instansi yang berkecimpung dibidang pengukuran arah kiblat seharunya melakukan kalibrasi secara menyeluruh untuk masjid-masjid yang ada, agar menambah keyakinan para jama'ah dalam melaksanakan salat.

Menghadap kiblat secara tepat merupakan perintah syari'at yang bersifat mutlak. Para fuqaha dan semua mujtahid sepakat bahwa menghadap Kakbah atau mengarah ke Kakbah ketika melaksanakan salat adalah wajib dan merukapan syarat sah salat. Karena syarat adalah sesuatu yang harus dipenuhi, maka tidak sah salat seseorang ketika tidak menghadap kiblat terkecuali dalam beberapa hal. Hal ini sesuai dengan hadits Rasulullah saw.:

"Ishaq bin Mansyur menceritakan kepada kita, Abdullah bin Umar menceritakan kepada kita, Ubaidullah menceritakan dari Sa'id bin Abi Sa'id al-Maqburiyi Dari Abi Hurairah r.a berkata Rasulullah saw. bersabda: Bila kamu hendak salat maka sempurnakanlah wudlu lalu menghadap kiblat kemudian bertakbirlah" (HR. Bukhari). ${ }^{2}$

Ali al-Sayis menyebutkan bahwa golongan Syafi'iyah dan Hanabilah menyatakan bahwa kewajiban menghadap kiblat tidaklah berhasil terkecuali bila menghadap 'ain-nya Kakbah. Hal itu berarti bahwa kewajiban ini harus dilakukan dengan tepat menghadap ke Kakbah.

Sementara golongan Hanafiyah dan malikiyah berpandangan bahwa bagi penduduk Makkah yang dapat menyaksikan Kakbah, maka wajib menghadap kepada 'ain-nya Kakbah, tetapi bagi yang tidak dapat menyaksikan Kakbah cukup dengan mengharap ke arahnya saja. Sedangkan yang dimaksud dengan arah Kiblat adalah arah atau jarak terdekat sepanjang lingkaran besar yang melewati kota Makkah (Kakbah) dengan tempat kota yang bersangkutan. ${ }^{3}$

1 Slamet Hambali, Ilmu Falak 1; Tentang Penentuan Awal Waktu Salat Dan Penentuan Arah Kiblat Di Seluruh Dunia (Semarang: Program Pascasarjana UIN Walisongo, 2011)., h. 58.

${ }^{2}$ Muhammad Ibnu Ismail Bukhari, Sahih AlBukhari (Beirut: Daar al-Kutub al-'Ilmiyyah, 1992)., h. 79.

${ }^{3}$ Hambali, Ilmu Falak 1; Tentang Penentuan Awal Waktu Salat Dan Penentuan Arah Kiblat Di Seluruh Dunia., h. 24. 


\section{AL-MARSHAD: JURNAL ASTRONOMI ISLAM DAN ILMU-ILMU BERKAITAN \\ ISSN 2442-5729 (print) || ISSN 2598-2559 (online) \\ http://jurnal.umsu.ac.id/index.php/almarshad \\ DOI: 10.30596/jam.v\%vi\%i.5229|| Vol. 6, No. 2 Desember 2020}

Berdasarkan kitab Fiqh Lima Mazhab, Imam Syafi'i menjelaskan bahwa wajib menghadap Kakbah, baik bagi orang yang dekat maupun orang yang jauh. Sekiranya dapat mengetahui arah Kakbah itu sendiri secara tepat, maka ia harus menghadap ke arah tersebut. Tetapi sekiranya tidak dapat memastikan arah Kakbah maka cukuplah dengan perkiraan karena orang yang jauh mustahil untuk memastikan ke arah kiblat (Kakbah) yang tepat dan pasti.

Dalam hal ini, berdasarkan realitas ketidakakuratan arah kiblat masjid Agung Meulaboh dengan sesuatu yang diharapkan oleh syari'at dalam menghadap kiblat, telah telah terjadi gap (kesenjangan), terlebih lagi kemiringan arah kiblat yang sangat jauh dari letak Kakbah itu sendiri. Sehingga perlu dilakukan penelitian lebih lanjut mengenai metode arah kiblat yang dilakukan.

\section{B. Metode Penelitian}

Peneliti menggunakan jenis penelitian lapangan, 4 untuk meneliti metode penentuan arah kiblat masjid Agung Baitul Makmur Meulaboh Aceh Barat. Dengan menelusiri historis pengukuran arah kiblat yang pernah dilakukan, akan digunakan metode azimuth kiblat dan rashdul kiblat untuk melakukan pengkalibrasian arah kiblat masjid Agung Baitul Makmur Meulaboh

4 Sumadi Suryabrata, Metodologi Penelitian, 10th ed. (Jakarta: PT. Raja Grafindo Persada, 1997)., h. 34.
Aceh Barat.

Data primer diperoleh dari hasil pengecekan arah kiblat masjid Agung Baitul Makmur Meulaboh Aceh Barat saat ini untuk mengetahui akurasi arah kiblatnya dengan menggunakan metode azimuth kiblat dan rashdul kiblat. Wawancara juga dilakukan untuk mengetahui sejarah pengukuran dan penyebab ketidak akuratan arah kiblat masjid tersebut.

Data primer yang akan digunakan dalam penelitian ini berasal dari bahan-bahan kepustakaan, di antaranya: ensiklopedi, bukubuku, artikel-artikel, karya ilmiah yang dimuat dalam media massa seperti majalah dan surat kabar, serta jurnal ilmiah maupun laporanlaporan hasil penelitian yang berkaitan dengan arah kiblat.

Data yang diperlukan dalam penulisan ini dengan observasi/pengamatan langsung ${ }^{5}$ untuk melakukan pengecekan arah kiblat masjid Agung Baitul Makmur Meulaboh Aceh Barat dengan metode azimuth kiblat diantara alat-alat yang digunakan antara lain: mizwala sebagai pengola data ephemeris secara mekanik dan diaplikasikan dalam menentukan arah kiblat, Google Earth sebagai alat elektronik untuk mengetahui lintang dan bujur tempat, dan metode rashdul kiblat. Penelitian ini juga melakukan wawancara guna mengumpulkan data terkait metode 


\section{AL-MARSHAD: JURNAL ASTRONOMI ISLAM DAN ILMU-ILMU BERKAITAN \\ ISSN 2442-5729 (print) || ISSN 2598-2559 (online) \\ http://jurnal.umsu.ac.id/index.php/almarshad \\ DOI: 10.30596/jam.v\%vi\%i.5229|| Vol. 6, No. 2 Desember 2020}

pengukuran dan penyebab terjadinya ketidak akuratan arah kiblat masjid Agung Baitul Makmur Meulaboh Aceh Barat.

Data yang terkumpul kemudian dipelajari dan dilakukan analisis data. Dalam menganalisis data penulis menggunakan tehnik analisis verifikasi dengan cara menguji kembali arah kiblat masjid masjid Agung Baitul Makmur Meulaboh Aceh Barat saat ini dengan metode metode azimuth kiblat diantara alat-alat yang digunakan antara lain: mizwala sebagai pengola data ephemeris secara mekanik dan diaplikasikan dalam menentukan arah kiblat, Google Earth sebagai alat elektronik untuk mengetahui lintang dan bujur tempat, dan metode rashdul kiblat/posisi matahari dijalur Kakbah. Tehnik analisis semacam ini disebut juga analisis kualitatif. ${ }^{6}$ Metode wawancara juga digunakan untuk mengetahui metode pengukuran dan penyebab terjadinya ketidak akuratan arah kiblat masjid Agung Baitul Makmur Meulaboh Aceh Barat.

\section{Hasil Dan Pembahasan}

\section{Hasil Penelitian}

Metode yang digunakan dalam memastikan kalibrasi dan akurasi arah

6 Tatang M. Amirin, Menyusun Rencana Penelitian (Jakarta: PT. Raja Grafindo Persada, 1995)., h. 24. kiblat masjid Agung Baitul Makmur

Meulaboh, diantararanya:

1) Kalibrasi Rashdul Kiblat Global

Rashdul kiblat merupakan satu-satunya metode penentuan arah kiblat yang bebas dari pengaruh bentuk Bumi. Untuk wilayah dekat kakbah, penentuan arah kiblat pada saat peristiwa ini dapat dilakukan dengan mudah karena Matahari masih cukup tinggi, misalnya untuk wilayah barat Indonesia.

Pada 27 dan 28 Mei tahun 2019. Sebagaimana yang telah penulis jelaskan di atas, bahwa rashdul kiblat merupakan salah satu metode yang akurat dalam mengkalibrasi arah kiblat. ${ }^{8}$ Data pada saat itu menunjukkan bahwa terjadi ketidak akuratan yang sangat signifikan pada masjid tersebut. Perhatikan gambar berikut!

7 Reza Akbar and Riza Afrian Mustaqim, "Problematika Konsep Bentuk Bumi Dan Upaya Mencari Titik Temunya Dalam Penentuan Arah Kiblat," Shar-E: Jurnal Kajian Ekonomi Hukum Syariah 6 (2020)., h. 56.

${ }^{8}$ Ahmad Izuddin, Ilmu Falak Praktis; Metode Hisab-Rukyat Praktis Dan Solusi Permasalahannya (Semarang: Pustaka al-Hilal, 2012)., h.71. 


\section{AL-MARSHAD: JURNAL ASTRONOMI ISLAM DAN ILMU-ILMU BERKAITAN \\ ISSN 2442-5729 (print) || ISSN 2598-2559 (online) \\ http://jurnal.umsu.ac.id/index.php/almarshad \\ DOI: 10.30596/jam.v\%vi\%i.5229|| Vol. 6, No. 2 Desember 2020}

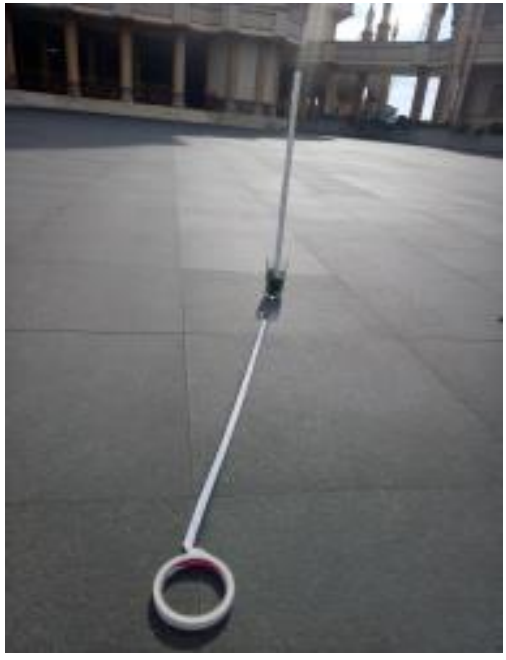

Gambar 1. Rashdul Kiblat Global 2019

Pada gambar 1 di atas, garis ubin/lantai merupakan arah kiblat yang sejajar dengan shaf di dalam masjid ataupun mihrab, sedangkan arah datang bayangan Matahari yang ditandai dengan double tip merupakan arah kiblat berdasarkan rashdul kiblat yang terjadi pada waktu tersebut. Artinya dalam hal ini kemiringan yang terjadi pada arah kiblat masjid agung mencapai 20 derajat. Jika dilakukan perpanjangan kepada bangunan Kakbah dari seliisih derajat tersebut pastinya akan sangat menlenceng jauh dari Kakbah mengingat jarak antara masjid agung dan Kakbah sangatlah jauh.

Selain itu, kalibrasi yang dilakukan pada tanggal 27 Mei 2020 juga menunjukkan hasil yang sama. Dimana arah kiblat masjid agung Meulaboh memiliki kemiringan yang sama dengan kalibrasi pada tahun sebelumnya. Posisi matahari di atas Kakbah bisa berlangsung lima sampai sepuluh menit. Pengamat yang tidak bisa tepat melakukan pengukurannya tepat waktu, bisa menyusulkan pada lima sampai sepuluh menit berikutnya. ${ }^{9}$

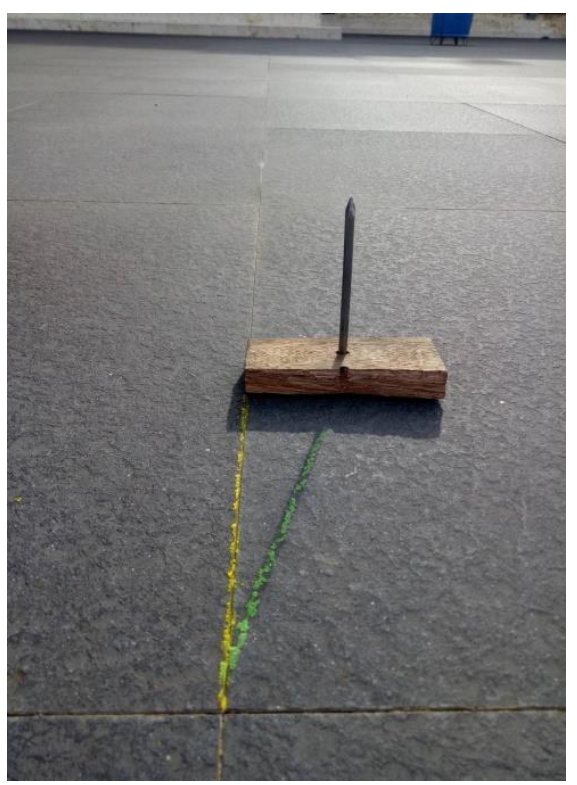

Gambar 2. Rashdul Kiblat Global 2020

Jika kita perhatikan gambar di atas, tidak ada perbedaan yang signifikan terkait kemiringan arah kiblat yang terjadi pada masjid agung Meulaboh. Perngkalibrasian yang berulang ini menunjukan keakuratan data pada saat pengamatan dilakukan. Hal ini dibutuhkan agar tidak terjadi kekeliruan atau human error yang dapat berdampak kepada keabsahan suatu data.

Berdasarkan pengkalibrasian pada tahun 2020 di atas, terdapat kemiriringan senilai $20^{\circ}$ dari arah kiblat sebenarnya (Kakbah). Itu artinya, arah kiblat masjid agung Meulaboh

9 Maesyaroh, "Akurasi Arah Kiblat Masjid Dengan Metode Bayang-Bayang Kiblat," Istinbath; Jurnal Hukum Islam 12 (2013)., h. 44. 
mengarah jauh ke sisi utara Kakbah. Hal ini merupakan suatu kemiringan yang tidak dapat ditoleransi. Selain berjarak jauh dari bangunan Kakbah ('ain ka'bah), arah kiblat masjid agung Meulaboh juga sama sekali tidak mengarah, meskipun ke arah dimana Kakbah berada.

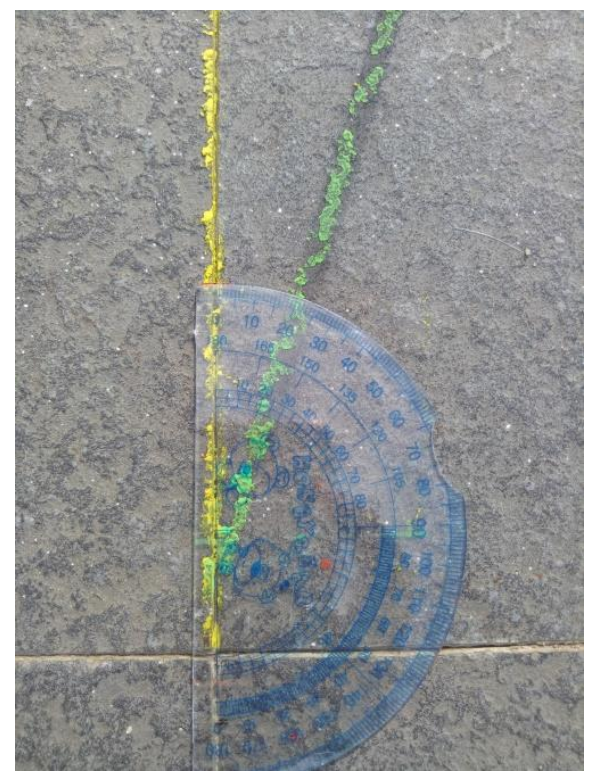

Gambar 3. Kemiringan dalam Derajat

\section{2) Kalibrasi Mizwala}

Mizwala merupakan sebuah alat praktis untuk menentukan arah kiblat secara praktis dengan menggunakan sinar Matahari. Penenntuan arah kiblat dengan Mizwala yaitu dengan menggunakan sinar Matahari, mengambil bayangan pada waktu yang dikehendaki. Kemudian bidang dial diputar sebesar sudut yang ada pada hasil perhitungan. Setelah itu lihat sudut azimuth kiblat tempat tersebut pada bidang dial dan tarik dengan benang. Garis tersebut adalah arah kiblat.

Berdasarkan pengkalibrasian arah kiblat masjid agung yang penulis lakukan, arah kiblat masjid agung meulaboh juga tidak akurat. Perhatikan gambar berikut!

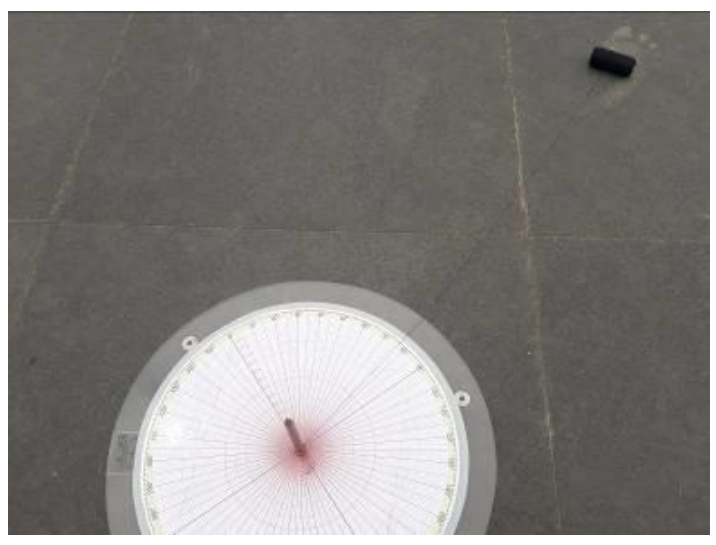

Gambar 4. Arah Kiblat Berdasarkan Pengukuran Mizwala

Jika kita perhatikan gambar 4 di atas, telihat juga kemiringan yang sangat signifikan pada arah kiblat masjid agung jika dikalibrasi menggunakan Mizwala.

Berdasarkan 2 metode di atas, penulis menemukan adanya ketidakakuratan yang cukup signifikan pada arah kiblat masjid agung. Kedua metode kalibrasi di atas menunjukan arah kiblat masjid agung melenceng ke arah Selatan bangunan Kakbah beberapa derajat. Meskipun sudut kemiringannya tidak sama atau berbeda tetapi dalam hal ini ketidakakuratan tersebut sudah dapat terlihat jelas berdasarkan dua metode di atas. 


\section{AL-MARSHAD: JURNAL ASTRONOMI ISLAM DAN ILMU-ILMU BERKAITAN \\ ISSN 2442-5729 (print) || ISSN 2598-2559 (online) \\ http://jurnal.umsu.ac.id/index.php/almarshad \\ DOI: 10.30596/jam.v\%vi\%i.5229|| Vol. 6, No. 2 Desember 2020}

Berisi data hasil penelitian yang didapat saat penelitian. Utamakan data hasil penelitian yang penting dan menjadi tujuan utama penelitian, atau data yang dapat dijadikan jawaban akan rumusan masalah dalam penelitian.

\section{Pembahasan}

1. Problematika Arah Kiblat Masjid Agung Meulaboh Aceh Barat

Ada dua macam penentuan arah kiblat, pertama; mencari arah kiblat yang harus persis menghadap ke Ka'bah ('ain al-ka'bah) sehingga harus mengambil posisi arah barat laut.Kedua; cukup mencari arahnya saja (jihhah al-ka'bah), tidak harus persis seperti cara yang pertama, maka arah barat persis sudahlah cukup dan apabila shalatnya menghadap kearah barat persis, shalatnya tetap sah. ${ }^{10}$

Menurut Badan Kemakmuran Masjid (BKM) tidak perlu dilakukan perubahan arah kiblat terhadap masjid Agung. Hal tersebut didasari pada lebih utamanya untuk menjaga kemashlahatan jamaah dan bangunan masjid yang sudah berdiri kokoh dengan kekhasan arsitek yang dimiliki. Selain itu, Tgk. H. Abdurrani Adyan (Majelis Permusyawaratan Ulama Aceh) berpandangan bahwa menghadap kiblat itu cukup dengan mengarah ke kota

10 Ngamilah, "Polemik Arah Kiblat Dan Solusinya Dalam Perspektif Al-Qur'an," Millati; Journal of Islamic Studie and Humanities 1 (2016)., h.86.
Mekkah, namun jika kondisinya seperti masjid Agung Meulaboh yang arah kiblatnya mengarah ke Ethiophia, maka cukup dengan meniatkan bahwa kita telah menghadap kiblat. Hal tersebut didukung dengan pemahaman dari kitab-kitab klasik. Dalam konteks penetapan hukum, Ulama dapat mengintegrasikan diri dalam mekanisme yang ada untuk berpartisipasi membentuk hukum dan opini legal. ${ }^{11}$

Menurut Kamil Syafruddin sejauh ini, dasar hukum penggunaan arah kiblat ini diantaranya: 1) Salatnya orang-orang terdahulu. Perubahan arah kiblat tertunya akan menimbulkan pertanyaan, apakah salat-salat orang terdahulu sah? 2) Pemahaman yang dibangun adalah kiblat zannī atau kiblat perkiraan dimana dalam hal ini setiap kita menghadap kiblat kita meyakini di dalam hati bahwa arah kita saat tersebut adalah Kakbah. Hal ini merupakan ruang lingkup ijtihadiya, dibutuhkan intensitas kesadaran yang tinggi bagi masyarakat.

Kamil Syafruddin berpendapat bahwa banyak yang setuju dengan perubahan arah kiblat tersebut, namun perlu menanamkan kesadaran kepada masyarakat guna menghindari konflik jika pada suatu waktu nanti perubahan arah kiblat tersebut dilakukan. Hal tersebut perlu dilakukan karena menghindari mudarat jauh lebih penting daripada mengambil manfaat. ${ }^{12}$

Sedangkan Cut Usman sendiri

11 Riza Afrian Mustaqim "Pandangan Ulama Terhadap Image Processing Pada Astrofotografi Di BMKG Untuk Rukyatul Hilal" Vol. 4, No. 1, 2018, h. 84. 2019). 


\section{AL-MARSHAD: JURNAL ASTRONOMI ISLAM DAN ILMU-ILMU BERKAITAN \\ ISSN 2442-5729 (print) || ISSN 2598-2559 (online) \\ http://jurnal.umsu.ac.id/index.php/almarshad \\ DOI: 10.30596/jam.v\%vi\%i.5229|| Vol. 6, No. 2 Desember 2020}

berpandangan bahwa menghadap kiblat itu wajib ke 'ain ka'bah, namun dalam konteks masjid Agung tersebut, banyak hal yang tidak bisa diungkapkan. Karena untuk melakukan perubahan arah kiblat harus melalui persetujuan banyak pihak.

Sejauh ini belum ada titik temu terkait arah kiblat masjid Agung, hanya saja untuk saat ini lebih mengedepankan untuk menghindari mudharat dari pada mengambil manfaat. Namun lambat laun, pola pikir masyarakat atau jama'ah akan berkembang sehingga akan lebih mudah dalam menerima perbedaan termasuk nantinya jika dilakukan perubahan terhadap arah kiblat. Namun untuk mencapai hal tersebut membutuhkan waktu.

Untuk menghindari mudharat, masyarakat dan jamaah perlu dijaga. Agar mereka dapat dan mampu memahami tentang teknologi terkait arah kiblat tidak bisa semertamerta terjadi, membutuhkan waktu yang cukup lama untuk menumbuhkan pemahaman tersebut. Sehingga untuk menghindari konflik antara sesama jama'ah atau antar kelompok dan golongan tertentu, maka memilih untuk tidak merubah arah kiblat adalah pilihan yang terbaik saat ini.

Dalam hal ini, pemahaman antara ilmu fiqh dan teknologi harus sejalan. Karena keduanya saling mendukung dan melengkapi antara satu dengan yang lainnya. Dalam permasalahan tertentu, sepertinya halnya arah kiblat, integrasi antara sains dan fiqh dibutuhkan agar dapat terpenuhinya dengan sempurna tujuan dari pensyariatan suatu hukum tertentu.

Secara umum, masyarakat atau jamaah tidak mengetahui terkait ketidak tepatan arah kiblat masjid Agung Baitul Makmur Meulaboh. Hanya saja beberapa jamaah mungkin sedikit tahu, namun tidak menelusuri lebih lanjut terkait hal tersebut. Hal seperti ini disatu sisi akan menjadi perbincangan banyak kalangan, jika tidak dibarengi dengan pemberian pemahaman terkait hal tersebut secara perlahan.

Sejauh ini, belum pernah dilakukan pengkalibrasian arah kiblat di masjid Agung, meski sekedar pengkalibrasian dengan Rashdul Kiblat Tahunan. Hal tersebut dipandang bisa memicu konflik antar jama'ah dan berakibat kepada kurangnya jamaah di masjid tersebut. Dalam hal ini juga Kementerian Agama Kabupaten Meulaboh yang di dalamnya terdapat Badan Hisab Rukyah yang mengurusi permsalahan yang berkaitan dengan ilmu falak (salah satunya arah kiblat) juga tidak memiliki peran yang signifikan terkait kondisi ini. ${ }^{13}$

2. Metode Penentuan Arah Kiblat Masjid Agung Baitul Makmur Meulaboh Aceh Barat

Tidak ada yang mengetahui pasti tentang metode awal yang digunakan pada saat pengukuran arah kiblat masjid Agung Baitul Makmur Meulaboh. Menurut Tgk. Cut Usman pengukuran arah kiblat pada awalnya hanya menerka-nerka arah barat saja, bahkan menurut keterangan beliau pembuatan mihrab ditentukan

${ }^{13}$ Wawancara Kamil., pada 23 Februari 2020. 


\section{AL-MARSHAD: JURNAL ASTRONOMI ISLAM DAN ILMU-ILMU BERKAITAN \\ ISSN 2442-5729 (print) || ISSN 2598-2559 (online) \\ http://jurnal.umsu.ac.id/index.php/almarshad \\ DOI: 10.30596/jam.v\%vi\%i.5229|| Vol. 6, No. 2 Desember 2020}

langsung oleh tukang pada saat itu. Pada saat peletakan batu pertama juga tidak melibatkan pimpinan dayah atau pemuka agama setempat. Sehingga dapat dikatakan peran tokoh agama saat itu sangat kurang, khususnya dalam pengukuran arah kiblat. Dan juga alat ukur untuk penentuan arah kiblat pada saat itu juga tidak memadai seperti saat ini. Ada satu toko yang masyhur dalam hal ilmu falak pada saat itu, tepatnya sebelum tsunami melanda Provinsi Aceh, yaitu Drs. Husaini namun tidak dapat dipastikan jika beliau berperan aktif dalam pengukuran arah kiblat pada saat itu. ${ }^{14}$

Ketua Pembangunan Masjid, Ramli Ploraga menerangkan pengukuran masjid Agung Meulaboh menggunakan kompas (namun kompas tidak terkalibrasi). Mihrab pernah tergeser arahnya oleh tukang. Tokoh agama tidak berperan dalam pengukuran arah kiblat, sehingga kiblatnya hanya sebatas perkiraan. Sedangkan untuk masjid Nurul Huda, masjid Agung sebelumnya arah kiblatnya tepat. ${ }^{15}$

Pada tahun 2013 pernah diadakan pertemuan yang membahas terkait arah kiblat masjid Agung Baitul Makmur Meulaboh, pertemuan tersebut dihadiri oleh Bupati Aceh Barat, Pengurus Masjid, Majelis Permusyawaratan Ulama Aceh Barat, Kementerian Agama Kabupaten Aceh Barat, Kepala BAPEDA danperwakilan intansi dan tokoh lainnya. Pertemuan yang diadakan di

14 Wawancara Cut Usman, pada 24 Februari 2020

15 Wawancara Kamil., pada 23 Februari aula Bupati tersebut memutuskan tetap mempertahankan arah kiblat yang berlaku saat ini. Dengan pertimbangan, jika dilakukan perubahan terhadap arah kiblat masjid selain merusak arsitektur masjid juga akan membingungkan jamaah. Dalam artian jamaah belum akan berselisih dengan perubahan arah kiblat tersebut. ${ }^{16}$

Menurut Kamil Syafruddin Diskusi tersebut berawal dari rencana pembentukan Badan Hisab Rukyah Kabupaten Meulaboh yang dihadiri oleh Tokoh Agama, Pekerja Umum (PU), Kemenag Kabupaten Aceh Barat, Pemerintah Daerah. Diskusi tersebut dipimpin oleh Bupati, H. T. Alaidin Syah. Tidak ada kesepakatan yang pasti pada saat itu terkait arah kiblat masjid Agung Meulaboh, hanya saja ketika ada suatu masjid baru yang ingin dibangun, maka perlu dilakukan pengukuran arah kiblat oleh BHR yang sudah dibentuk. Adapun SOP yang diterapkan dalam pengukuran tersebut adalah: 1) Tidak boleh mengusik arah kiblat lama pada suatu Masjid, 2) Pengukuran dilakukan berdasarkan permintaan tertulis dari pihak pembangunan masjid, 3) Pengukuran arah kiblat tidak boleh terjadi konflik. ${ }^{17}$

3. Tidak Adanya Metode yang Pasti dalam Pengukuran Awal

Secara historis cara penentuan arah kiblat di Indonesia mengalami perkembangan sesuai dengan kualitas dan kapasitas intelektual di kalangan 2020.

2020.

${ }^{16}$ Wawancara Cut Usman, pada 24 Februari

${ }^{17}$ Wawancara Kamil., pada 23 Februari 2020. 


\section{AL-MARSHAD: JURNAL ASTRONOMI ISLAM DAN ILMU-ILMU BERKAITAN \\ ISSN 2442-5729 (print) || ISSN 2598-2559 (online) \\ http://jurnal.umsu.ac.id/index.php/almarshad \\ DOI: 10.30596/jam.v\%vi\%i.5229|| Vol. 6, No. 2 Desember 2020}

kaum muslimin. ${ }^{18}$ Secara umum di Indonesia banyak masjid-masjid yang dibangun pada tahun 1990-an bermasalah arah kiblatnya. Ada beberapa faktor yang menyebabkan hal itu terjadi, salah satunya adalah belum memadainya metode pengukuran yang berkembang, baik dari segi perhitungan, maupun peralatan yang digunakan. Hal yang serupa juga terjadi pada penentuan arah kiblat pada masjid agung Baitul Makmur.

Tidak ada yang mengetahui secara pasti bagaimana pengukuran arah kiblat pada masjid tersebut pada awalnya. Tingkat kemiringan yang cukup besar, tentunya bermuara pada ketidakpastian metode yang digunakan pada saat pengukuran awal. Jika kita mengacu pada metode-metode tradisional, seyogyanya kemiringan atau kurang tepatnya arah kiblat juga terjadi. Tetapi masih dalam kategori wajar, sehingga perubahan yang perlu dilakukanpun tidaklah terlalu signifikan. Namun tingkat kemiringan yang terjadi pada masjid agung, sudah tidak mengarah sama sekali. Hal ini menjadi sebuah masalah besar bagi sebuah masjid kabupaten/kota. Masjid dengan kapasitas jamaah yang lebih banyak dan sebagai sentral bagi masjid-masjid lainnya seudah seharunya memiliki arah kiblat yang tepat. Dalam artian, akan ada paragdigma yang berkembang pada masyarakat untuk mengacu kepada arah yang dituju oleh masjid agung

18 Imroatul Munfaridah, "Studi Kritik Terhadap Penentuan Arah Kiblat Dan Awal Bulan Qamariyah Pemikiran Kh. Ahmad Dahlan," Jurisdictie, Jurnal Hukum Dan Syariah 2 (2011), h. 64 . dalam menghadap kiblat, baik di rumah masyarakat, kantor pemerintahan, pusat keramaian, ataupun masjid dan mushalla yang berada disekitanya.

Dalam hal ini, pengkalibrasian arah kiblat masjid agung merupakan suatu keharusan yang mendesak. Ada banyak faktor yang perlu dihindari dalam mempertahankan arah kiblat yang ada. Pertama, diperbolehkan menghadap kiblat dengan arah jihatul ka'bah. Hal ini berlaku kepada selain penduduk makkah, artinya penduduk atau umat muslim yang berada jauh dari kakbah atau tidak dapat melihat Kakbah. Namun keberlakuan tersebut tidak dapat digunakan jika suatu penduduk negeri memilki kemampuan untuk bisa menghadap kiblat secara tepat. Artinya berargumentasi menghadap kiblta ke arah jihatul $k a$ 'bah tidak dapat digunakan.

Kedua, kekeliruan pada saat awal pengukuran arah kiblat karena keterbatasan pengetahuan. Perlu dipahami bahwa ada banyak masjid yang kurang tepat arahnya dalam menghadap kiblat, namun dengan perkembangan metode yang terjadi mayoritas masjid lebih menerima untuk melakukan pengkalibrasian arah kiblat untuk dapat menghadap secara tepat. Namun hal ini tidak berlaku pada masjid agung Baitul Makmur Meulaboh. Pasalanya, banyak pertimbangan yang sukar untuk menerima perubahan tersebut.

Di sisi lain, terdapat salah satu masjid Nurul Huda $^{19}$ yang letaknya tidak terlalu jauh dari masjid agung Baitul Makmur. Dimana masjid tersebut

${ }^{19}$ Masjid Nurul Huda merupakan masjid agung di kabupaten Aceh Barat sebelum masjid Baitul Makmur. 


\section{AL-MARSHAD: JURNAL ASTRONOMI ISLAM DAN ILMU-ILMU BERKAITAN ISSN 2442-5729 (print) || ISSN 2598-2559 (online) \\ http://jurnal.umsu.ac.id/index.php/almarshad \\ DOI: 10.30596/jam.v\%vi\%i.5229|| Vol. 6, No. 2 Desember 2020}

mengarah ke arah Kakbah. Meskipun tidak tepat ke 'ainul ka'bah akan tetapi secara arah sudah mengarah ke Kakbah. Berdasarkan hal ini, bisa saja pengetahuan tentang menentukan arah kiblat sudah berkembang berdasarkan metode klasik pada saat itu. Sehingga di sisi lain, penyebab ketidakpastian metode yang diterapkan di dalam penentuan arah kiblat bukan hanya permasalahan human error melainkan juga kurangnya peran tokoh agama setempat, yang akan dijelaskan pada pembahasan berikutnya.

\section{Dampak Keditakpastian Metode}

\section{Pengukuran; Kiblat Zannī}

Menurut Ismail kiblat zann̄̄ adalah arah terdekat suatu tempat ke Kakbah yang berpatokan pada lingkaran besar bola bumi (360 derajat) yang melewati suatu tempat dan Kakbah. Arah terdekat ditunjuki oleh nilai azimut yang dihitung menggunakan teori geometri bola dan diimplementasikan dengan instrumen yang paling akurat yaitu theodolit. ${ }^{20}$

Terdapat perbedaan yang sangat signifikan antara kiblat ẓannī yang dimaksud oleh pakar ilmu falak dengan hasil interview yang penulis lakukan. Kiblat z̧ann̄̄ yang dipahami dalam kalangan ilmu falak berdasarkan hasil perhitungan dan pengukuran matematis, sedangkan data yang penulis dapatkan di lapangan kiblat zannī yang

${ }^{20}$ Ismail, "Urgensi Dan Legitimasi Fatwa Majelis Permusyawaratan Ulama Aceh Nomor 3 Tahun 2018 Tentang Penetapan Arah Kiblat," AlManahij 14 (2020)., h. 67. dimaksud lebih kepada dugaan kuat bahwasanya pada saat melaksanakan salat arahnya sudah tepat ke Kakbah. Sehingga perlu penulis tekankan, bahwa penjelasan tentang kiblat zannī berikutnya yang dimaksud adalah dugaan kuat arah kiblat sudah tepat.

Pemahaman kiblat zann̄̄ tidak lagi relevan digunakan di tengah banyaknya alternatif untuk bisa menghadap kiblat secara tepat. Kiblat zannī dapat digunakan bagi suatu penduduk atau seorang muslim yang kesulitan dalam mengetahui arah kiblat yang tepat. Artinya hal tersebut tidak berlaku bagi suatu penduduk yang di dalamnya terdapat orang yang cakap dan mampu dalam melakukan pengukuran arah kiblat secara tepat.

Banyak pihak yang memilih untuk mempertahankan kiblat masjid agung Baitul Makmur Meulaboh yang saat ini, dengan alasan menjaga jamaah dan menghindari mudharat. Karena akan ada perdebatan bagaimana salat-salat orang terdahulu jika selama ini kiblat yang dituju tidak benar? Apakah sah atau sebaliknya? Kemudian banyak pihak yang beranggapan merubah atau mengkalibrasi arah kiblat akan berdampak pada munculnya perselisihanperselihan, sehingga hal itu lebih baik untuk dihindari.

Secara normatif, tinggkat kemiringan arah kiblat yang terjadi dimasjid agung tidak dapat ditoleransi lagi karena cukup jauh bergeser dari arah Kakbah, pun juga 'Ainul Ka'bah. Jika mengacu kepada pendapat Thomas Djamaluddin, batas toleransi kemiringan arah kiblat adalah $2^{\circ}$ 


\section{AL-MARSHAD: JURNAL ASTRONOMI ISLAM DAN ILMU-ILMU BERKAITAN \\ ISSN 2442-5729 (print) || ISSN 2598-2559 (online) \\ http://jurnal.umsu.ac.id/index.php/almarshad \\ DOI: 10.30596/jam.v\%vi\%i.5229|| Vol. 6, No. 2 Desember 2020}

derajat. ${ }^{21}$ Sedangkan menurut Muh. Ma'rufin Sudibyo untuk daerah Indonesia, nilai ikhtiyatul qiblat-nya adalah $0,5^{\circ} .{ }^{22}$ Dalam konteks ini, ketika sudah ada yang pihak yang mencoba melakukan pengkalibrasian arah kiblat atau pihak yang dipandang cakap dan mampun untuk melakukan pengukuran arah kiblat yang tepat (seperti BHR kabupaten/kota Aceh Barat) maka seharusnya, yang dipertanyakan adalah bagaimana salat orangorang yang telah mengetahui bahwa arah kiblat pada suatu masjid jauh bergeser dari arah seharusnya? apakah sah atau sebaliknya?

Dalam pengertian kalibrasi arah kiblat, bila hasil kalibrasi arah kiblat menunjuki arah bangunan masjid dalam rentang toleransi, maka saf masjid tersebut tidak perlu diperbaiki. ${ }^{23}$ Namun berbeda pada masjid yang tidak kemiringannya tinggi, bisa saja untuk merubah saf tidak dimungkinkan lagi, sehingga harus merobohkan bangunan masjid.

Permasalahan di atas bukan lagi tentang bagaimana mempertahankan pemahaman kiblat z̧ann̄ yang tidak lagi relevan. Akan tetapi adanya persamaan kesepakatan bersama tentang betapa pentingnya kiblat tersebut dikalibrasi perlu dilakukan. Mengingat kemiringan yang terjadi pada arah kiblat

21 Djamaluddin Thomas, "Arah Kiblat Tidak Berubah,” 2010, https://tdjamaluddin.wordpress.com/2010/05/25/ara h-kiblat-tidak-berubah/.

${ }^{22}$ Muh.Ma'rufin Sudibyo, Sang Nabi Pun Berpitar; Arah Kiblat Dan Tat Cara Pengukurannya (Solo: Tinta Medina, 2011)., h.43.

${ }^{23}$ Ismail, "Standar Operasional Prosedur (SOP) Kalibrasi Arah Kiblat Masjid Di Era Digital," Al-Marshad 5 (2019): 110., h. 65. masjid tersebut bukan pada batasan wajar atau batasan yang dapat dimaklumi.

Problem jamaah tidak banyak terlalu perduli terkait hal tersebut, sudah semestinya pemimpinlah yang mengambil peran dalam meluruskan hal tersebut. Memberikan pemahaman kepada jamaah dari berbagai sudut pandang sehingga pada akhirnya jamaahpun pahan akan kondisi yang ada dan menerima adanya pengkalibrasian arah kiblat. Pola pemahaman ini tidak lain disebabkan adanya integrasi tuntunan agama, pengetahuan ilmu geografi dan astronomi, serta tuntutan perawatan maupun perubahan pada desain Masjid sebagai tempat ibadah yang akan sering sekali dikunjungi publik umumnya. ${ }^{24}$

Menurut Syeikh Daud bin Abdullah Fatoni dalam kitabnya Bughyatul Tullab menyatakan bahwa dalam suatu kampung, kota dan sebuah negara wajib menyediakan seorang yang mahir ataupun cakap dalam menentukan arah kiblat. Dr. Hamka juga menafsiri Q.S al-Baqarah, ayat 149, beliau menyatakan bahwa kesungguhan melaksanakan perintah menghadap kiblat adalah untuk mereka yang sanggup belajar ilmu falak, maka sesungguhnya Allah swt., tidak sekali-kali mengabaikan kesungguhan tersebut untuk diganjari-Nya nanti. ${ }^{25}$

Sedangkan Sayyidi Sabiq menjelaskan bahwa menghadap kiblat bagi yang dapat langsung melihat Kakbah wajib berusaha agar dapat

${ }^{24}$ Anisah Budiwati and Saiful Aziz, "Akurasi Arah Kiblat Masjid Di Ruang Publik," Jurnal Sains Sosial Dan Humaniora 1 (2018).,h. 64

${ }_{25}$ Jani Mohamad Faizal bin, Muzakirah Ilmu Falak, (Kumpulan Nota-Nota Ilmu Falak Untuk Dua Belas Bulan), n.d., h. 65. 


\section{AL-MARSHAD: JURNAL ASTRONOMI ISLAM DAN ILMU-ILMU BERKAITAN \\ ISSN 2442-5729 (print) || ISSN 2598-2559 (online) \\ http://jurnal.umsu.ac.id/index.php/almarshad \\ DOI: 10.30596/jam.v\%vi\%i.5229|| Vol. 6, No. 2 Desember 2020}

menghadap persis ke Kakbah, sedangkan bagi yang tidak secara langsung menghadap Kakbah karena terhalang atau jauh, hanya wajib menghadap ke arah kiblat. ${ }^{26}$

Dalam hal ini keharusan menghadap kiblat dengan tepat merupakan suatu hal yang mendesak jika dalam suatu penduduk negeri terdapat orang yang mampu dalam melakukan hal tersebut. Sehingga tidak dapat kiblat ditentukan atau diyakini atas dasar keyakinan yang kuat (zannī $i)$ saja.

\section{Kesimpulan}

Pengukuran Arah Kiblat Masjid Agung Baitul Makmur Meulaboh Aceh Barat tidak mengacu pada suatu metode pengukuran tertentu, sehingga berdampak kepada ketidakakuratan yang sangat signifikan (tidak mengarah, meskipun ke jihatul ka'bah). Ada yang menyebutkan pengukuran awalnya hanya mengacu kepada kompas, ada juga yang menjelasakan tentang adanya kesalahan (human error) pada saat pembuatan mihrab pada masjid tersebut. Kekurangan ini sangat mungkin terjadi sehingga menghasilkan kemiringan yang sangat besar.

${ }^{26}$ Sabiq Sayyid, Fiqh Sunnah, I, 1971., h.

\section{Daftar Pustaka}

Akbar, Reza, dan Riza Afrian Mustaqim. 2020. "Problematika Konsep Bentuk Bumi Dan Upaya Mencari Titik Temunya Dalam Penentuan Arah Kiblat." Shar-E: Jurnal Kajian Ekonomi Hukum Syariah 6

Budiwati, Anisah, and Saiful Aziz. 2018. "Akurasi Arah Kiblat Masjid Di Ruang Publik.” Jurnal Sains Sosial Dan Humaniora 1.

Bukhari, Muhammad Ibnu Ismail. 1992. Sahih AlBukhari. Beirut: Daar al-Kutub al-'Ilmiyyah, Cut, Usman. 2019. "Interview.” Meulaboh. Hambali, Slamet. 2011. Ilmu Falak 1; Tentang Penentuan Awal Waktu Salat Dan Penentuan Arah Kiblat Di Seluruh Dunia. Semarang: Program Pascasarjana UIN Walisongo.

Ismail. 2019. "Standar Operasional Prosedur (SOP) Kalibrasi Arah Kiblat Masjid Di Era Digital." Al-Marshad 5: 110.

Ismail. 2020. "Urgensi Dan Legitimasi Fatwa

Majelis Permusyawaratan Ulama Aceh Nomor 3 Tahun 2018 Tentang Penetapan Arah Kiblat." Al-Manahij 14.

Izuddin, Ahmad. 2012. Ilmu Falak Praktis; Metode Hisab-Rukyat Praktis Dan Solusi Permasalahannya. Semarang: Pustaka alHilal.

Kamil, Syafruddin. 2019. "Interview.” Meulaboh.

M. Amirin, Tatang. 1995. Menyusun Rencana Penelitian. Jakarta: PT. Raja Grafindo Persada.

Maesyaroh. 2013. "Akurasi Arah Kiblat Masjid Dengan Metode Bayang-Bayang Kiblat.” Istinbath; Jurnal Hukum Islam 12.

78. 
Mohamad Faizal bin, Jani. Muzakirah Ilmu

Falak, (Kumpulan Nota-Nota Ilmu Falak

Untuk Dua Belas Bulan), n.d.

Riza Afrian Mustaqim, 2018. "Pandangan

Ulama Terhadap Image Processing Pada

Astrofotografi Di BMKG Untuk

Rukyatul Hilal” Vol. 4, No. 1.

Munfaridah, Imroatul. 2011. "Studi Kritik

Terhadap Penentuan Arah Kiblat Dan

Awal Bulan Qamariyah Pemikiran Kh.

Ahmad Dahlan.” Jurisdictie, Jurnal

Hukum Dan Syariah 2.

Ngamilah. 2016. "Polemik Arah Kiblat Dan

Solusinya Dalam Perspektif Al-Qur'an.”

Millati; Journal of Islamic Studie and

Humanities 1.

Sayyid, Sabiq. 1971. Fiqh Sunnah. I.

Sudibyo, Muh.Ma'rufin. 2011. Sang Nabi Pun

Berpitar; Arah Kiblat Dan Tat Cara

Pengukurannya. Solo: Tinta Medina.

Sumadi Suryabrata. 1997. Metodologi

Penelitian. 10th ed. Jakarta: PT. Raja

Grafindo Persada.

Thomas, Djamaluddin. "Arah Kiblat Tidak

Berubah," 2010.

https://tdjamaluddin.wordpress.com/2010

/05/25/arah-kiblat-tidak-berubah/.

diakses pada tanggal 12 Oktober 2020. 